\title{
Classification and Evaluation of Internal Transaction Expenses Emerging during Conduct of Managerial Activities
}

\author{
Lyubov N.Chaykovskaya (Dmitrieva) \\ Viktoria V. Grigoryeva \\ Julia N. Duvanova \\ Olga M. Pasynkova \\ Kirill V. Chekudaev \\ Voronezh State University of Engineering Technologies, Russian Federation \\ Correspondence: Viktoria V. Grigoryeva, Voronezh State University of Engineering Technologies, Russian Federation \\ Email: vickierus@mail.ru; lubovdmitr@yandex.rudyvanova@mail.ru,olga.pasol@yandex.ru, kirillchek@yandex.ru
}

Doi:10.5901/mjss.2015.v6n6s4p376

\section{Abstract}

The purpose of this work is to develop theoretical and scientific \& methodological provisions in the sphere of institutional management of industrial enterprises; the main task of the research is to determine and classify internal transaction costs of the process of management of industrial enterprise. The article offers the hypothesis that transfer of institutional theoretical concepts to micro-level - in particular, to the level of management - of industrial enterprise, with further specification and development, will allow perfecting the process of management and increasing its effectiveness. The research showed that there is no generally recognized classification of transaction expenses. As a result of the research, the authors offer classification of internal transaction expenses that emerge during the process of managerial activities. The given classification allows managers to see which transaction expenses are related to implementation of managerial functions, provide basis for development of the system of evaluations of internal transaction expenses of industrial company which allows simplifying evaluation of effectiveness of managers' work and use of specific managerial tools, and allows managers to allocate the reserves for growth in the sphere of management of industrial enterprise. The set goal of the research work; requirements to final results of the research, to their precision and authenticity; limitations of resources, possibilities of research, and technical means used for the research predetermined the use of the following general scientific methods: logical analysis and synthesis during the study of opinions of various authors on classification of transaction expenses, functional approach during allocation of the most significant problems which appear during implementation of main managerial functions at industrial enterprises, ranking, grouping, expert evaluations, surveys during development of the list of criteria that reflect the most characteristic types of transaction expenses as to top-priority types of managers' activities.

Keywords: internal transaction expenses, management of industrial enterprise.

\section{Introduction}

Evolution of management, as a science, shows that institutional problems were always within the field of managerial activities - however, only in the second half of the XX century the issues of formation and development of institutional processes and their influence on the functioning of economic systems came to the foreground in the professional research. It was mainly caused by the fact that modern economic realias actualize before the scientific thought the tasks, solving of which within neo-classic theory (mainstream economics) is not just very difficult, but methodologically limited.

These and other circumstances, related to the necessity for perfecting the system of economic systems management, make the researchers to take the path of expansion of conceptual framework and sphere of analysis of economic science - at that, one of the perspective directions of scientific search is basic provisions of institutional theory.

Under the conditions of total globalization and strengthening of competition, the determining factor of success is capability for quick adaptation to changes of external environment and acquiring new effective methods and approaches in production \& economic and managerial activity of industrial enterprise. One of perspective approaches that facilitate the formation of the mechanism of sustainable functioning and development is institutional one. However, as the analysis of bibliographical sources shows, this approach is actively viewed in relation to macro-economic problems, while it is not used at micro-economic level. Due to that, the study of the possibility of use of basic theoretical provisions of institutional approach for description of peculiarities of managerial activities poses significant scientific interest. In our opinion, use of popular institutional concepts of macro-economics in relation to management of industrial enterprises will allow increasing 
the effectiveness of their management.

One of the basic components of new institutional economic theory is the theory of transaction expenses. Making the transaction expense a separate article will allow simplifying the evaluation of effectiveness of industrial enterprises manager's work and use of specific managerial tools. Thus, the determination of the most popular transaction expenses, related to managerial activities, and their classification is very actual.

Classification will allow managers of industrial enterprises to see which transaction costs will accompany the performance of managerial functions, will provide basis for development of the system of evaluation of internal transaction costs of industrial enterprise, and will allow managers to determine reserves of growth in the sphere of industrial enterprise management.

This research uses scientific provisions on the studies issues by Russian and foreign economists. Top-priority developments of basic scientific provisions of institutional theory belong to foreign leading researchers, including $T$. Veblen, J. Commons, W. Mitchell, R. Coase, D. North, J. Wallace, C. Menger, J. Hongson, etc. Problems of management of sectorial enterprises are the object of study of the following economists: Y.P. Anisimov, V.M. Bautin, Y.A. Salikov, A.I. Khorev, I.P. Bogomolova, V.P. Voronin, V.G. Zakshevsky, G.I. Tamoshin, L.V. Shulgina, etc. However, these works do not reflect specific issues which are related to the use of basic theoretical provisions of institutional approach to description of peculiarities of modern management of industrial enterprise.

\section{Literature Review}

Initially, transaction expenses were defined by R. Cose as "expenses for use of market mechanism" (Cose R., 1993). Later, this notion acquired wider sense. It began denoting any types of expenses which arise during cooperation of economic agents regardless of where it takes place - in the market or within organizations, as business cooperation within hierarchical structures (like companies) is not free of tensions and losses. According to the most recognized definition by $\mathrm{C}$. Dalman, transaction expenses include expenses of collection and processing of information, conduct of negotiations and decision making, control for contract observation, and their enforcement (Tambovtsev V.L., 2006).

It should be noted that general classification of transaction expenses is not available, for each of the researchers paid attention to the most interesting - from their point of view - elements. G. Stigler distinguished "informational expenses" (Institutional economics, V.M. Vasiltsova, S.A. Tertyshny, 2013), O. Williamson - "expenses of opportunistic behavior" (Institutional economics, G.N. Makarova, V.A. Rudyakova, 2014), M. Jensen and W. Meckling - "expenses for monitoring the agent's behavior and expenses of self-limitation" (Institutional economics, O.S. Sukharev, 2014), Y. Barzel - "expenses of measurement" (Institutional economics, G.N. Makarova, V.A. Rudyakova, 2014), P. Milgrom and J. Roberts - "expenses of influence" (Institutional economics, O.S. Sukharev, 2014), G. Hansmann - "expenses for collective decision making" (Institutional economics, E.V. Ustyuzhanina, 2015). C. Dalman included into them "expenses of collection and processing of information, expenses of conduct of negotiations, and expenses for control and legal protection of contract observation" (Rysmyatov A.Z., 2008).

The supporters of transaction approach allowed various classifications of transaction expenses (costs). K. Menar distinguishes four types of transaction expenses:

expenses of division, caused by various levels of technological division of production operations;

coding of expenses for transfer and decipher of signal, and training of user;

expenses of scale, caused by the system of impersonal exchange, and requiring the system of provision of contract observation;

expenses of opportunistic behavior, caused by expenses for punishment of violators of contract agreements (Hodgson, J., 2003).

J. Wallison and D. North distribute expenses according to the stages of the process of contractions, into which the following types of transaction expenses should be included:

expenses which emerge before the exchange (expenses for acquiring information on prices and possible alternatives, quality of product and reliability of agents);

expenses emerging in the process of exchange (expenses related to waiting in lines, receipt of notarized documents, insurance, and performance of calculations);

expenses emerging after exchange (expenses for contract protection, verification and control of their fulfillment) (Institutional economics, E.V. Ustyuzhanina, 2015).

Such distribution of the term "transaction expenses", in view of time of the deal, gives reason for choosing the forms of institutional protection depending on individual norms of discounting.

In their classification, E. Furubotn and R. Richter substantiate the division of transaction expenses as to spheres of emergence. According to this methodology, transaction expenses are divided into: 

process);

market (expenses for searching partners and information, negotiations, decision making, and monitoring of

managerial (expenses for development, implementation, support, and change of organizational structures);

political (expenses for creation and support of political system: legal, arbitral, defense, educational, and transport) (Furubotn E.G., Richter R., 2005).

A.E. Shastitko offers his own classification of transaction expenses, trying to summarize the typologies of previous authors. He distinguishes six types of transaction expenses:

expenses for alternatives allocation;

expenses for payments;

expenses for measurement;

expenses for contract;

expenses for specification and protection of ownership rights;

expenses of opportunistic behavior (Shastitko A.E., 2002).

However, the given classifications of transaction expenses do not fully reflect internal transaction expenses which emerge in the process of management of industrial enterprise.

Within this article, the most interesting are the transaction expenses that emerge within industrial enterprise and are related to conduct of managerial activities - particularly, ones that emerge in the process of fulfillment of managerial functions. Managerial functions are determined as specific types of activities which are necessary for organization and management.

\section{Discussion and Results}

In order to determine transaction expenses that emerge in the process of fulfillment of managerial functions, we described the main functions of management and conducted the research for determining the most popular problems which emerge during their implementation. At present, various authors offer a large number of categories as general managerial functions. Within this research, in the basis of works by Y.A. Salikova, the main functions of management are: organization, planning, coordination, motivation, and control (Salikov Y.A., 2008).

This analysis was performed on the basis of study of various bibliographic sources (Lafta J.C., 1999; Thompson A.A.. 1998; Drucker P.P., 2000; Kreiner C., 2002; Novikov D. A., 2003 et al.), opinions of scientists in the sphere of industrial enterprise management, and opinions of managers (of higher, medium, and lower levels) of food production companies (Khorev A.I., Salikov Y.A., Dmitrieva L.N., 2009). The main received results are shown in Table 1.

Table 1. The most significant problems during implementation of main managerial functions at industrial enterprises

\begin{tabular}{|c|c|c|}
\hline Managerial functions & Content of managerial functions & $\begin{array}{l}\text { The most significant problems during implementation of } \\
\text { managerial functions }\end{array}$ \\
\hline Organizational function & $\begin{array}{l}\text { Formation of controlled and managing sub-systems, } \\
\text { setting the specific parameters and regimes of work of } \\
\text { departments, enterprises, and relations between them }\end{array}$ & $\begin{array}{l}\text { Systemic problems, problem of flexibility of reaction to changes, } \\
\text { problems of work with external environment, problems with } \\
\text { fulfillment of documents and orders, problem of transfer of } \\
\text { information between the object and subject of management. }\end{array}$ \\
\hline Function of planning & $\begin{array}{l}\text { Prediction of the process of economic development for } \\
\text { future period for specific organization allows determining } \\
\text { what is to be achieved and what tools should be used, in } \\
\text { view of time and space. }\end{array}$ & $\begin{array}{l}\text { The problem of target setting, unclear idea of strategic goals and } \\
\text { tasks, incomplete determination of external and internal } \\
\text { conditions. }\end{array}$ \\
\hline Function of coordination & $\begin{array}{l}\text { Provision of coordination of all links of management } \\
\text { system, preservation, support, and perfection of the set } \\
\text { regime of work of production mechanism }\end{array}$ & $\begin{array}{l}\text { Problems related to labor division in management apparatus, } \\
\text { problem of conflicts, problems related to availability of single data } \\
\text { base, informational closeness of particular structural links, } \\
\text { problem of uncertainty in distribution and formulations of } \\
\text { responsibility, authorities, and rules of cooperation. }\end{array}$ \\
\hline Motivation & $\begin{array}{l}\text { Process of motivating oneself and others for achievement } \\
\text { of personal goals and (or) organization's goals }\end{array}$ & $\begin{array}{l}\text { Problem of prejudiced recruitment, problem of development of } \\
\text { staff and their training, problem of attitude towards employees as } \\
\text { to means of goal achievement without own ambitious goals and } \\
\text { striving for development. }\end{array}$ \\
\hline Control & $\begin{array}{l}\text { Process of provision of achievement of organization's } \\
\text { goals. The process of control consists of measurement of } \\
\text { achieved results and conduct of corrections in case the } \\
\text { achieved results substantially differ from the set ones }\end{array}$ & $\begin{array}{l}\text { Problems of evaluation of effectiveness of manager's work, } \\
\text { problem of analysis and audit of managerial activities, } \\
\text { management systems, due to the fact that, as of now, there is no } \\
\text { methodology of determining the effectiveness of the management } \\
\text { system which reflects all specific peculiarities of managerial } \\
\text { activities. }\end{array}$ \\
\hline
\end{tabular}


Based on the conducted analysis, we determined the most vivid and popular transaction expenses which emerge during implementation of managerial functions (Table 2).

Table 2. Transaction expenses which emerge during implementation of managerial functions

\begin{tabular}{|c|c|c|c|c|c|}
\hline \multicolumn{6}{|c|}{ Functions of management } \\
\hline & Organizational & Planning & Coordination & Motivation & Control \\
\hline & $\begin{array}{l}\text { Expenses for reconsidering the } \\
\text { terms of functioning; expenses for } \\
\text { ineffective reaction to changed } \\
\text { conditions; expenses for } \\
\text { "negotiations"; development and } \\
\text { correction of organizational } \\
\text { structure, distribution of } \\
\text { resources, etc. }\end{array}$ & \begin{tabular}{|l|} 
Expenses for search \\
for information, \\
expenses for changing \\
plans, for development \\
and correction of goals, \\
allocation of resources \\
and their provision, etc.
\end{tabular} & $\begin{array}{l}\text { Expenses for influence, } \\
\text { expenses for collective } \\
\text { decision making, expenses } \\
\text { for production meetings, } \\
\text { expenses for provision of } \\
\text { parties' interests, } \\
\text { maneuvering the resources, } \\
\text { coordination of plans, etc. }\end{array}$ & $\begin{array}{l}\text { Expenses for protection } \\
\text { of employees' rights, } \\
\text { expenses for } \\
\text { opportunistic behavior, } \\
\text { expenses for non- } \\
\text { material bonuses, etc. }\end{array}$ & $\begin{array}{l}\text { Expenses for } \\
\text { information } \\
\text { processing, expenses } \\
\text { for measurement, } \\
\text { expenses for } \\
\text { alternatives } \\
\text { determination. }\end{array}$ \\
\hline
\end{tabular}

During the performance of organizational function, the following types of transaction expenses emerge most often: expenses for reconsideration of functioning terms - emerge due to alternative of choice of various organizational systems, various work regimes, and relations between departments;

expenses for ineffective reaction to changed conditions - emerge with taking the less profitable alternative, which leads to reduction of effectiveness of managerial activities and enterprise on the whole;

expenses for "negotiations" - emerge in return for the problem of transfer of information between subject and object of management; information that is not understood right or arrived late leads to certain losses which could be expressed in reduction of products quality, manufacture of products in assortment that does not correspond to demand, etc.

During implementation of the function of planning, the following types of transaction expenses arise most often:

expenses for information search - expenses of time and resources for receiving and processing of required information;

expenses for change of plans - expenses of time and resources for change and correction of plans.

The function of coordination is related to the following types of transaction expenses:

expenses for influence - related to centralized management; they consist in setting the certain limitations for activities of particular departments. For example, transfer of employee from one department to another, outstripping growth rates of wages of certain employees as compared to others, re-direction of investments between production departments which leads to employees' trying to influence decisions made by the management, which leads to loss of time and resources.

expenses for collective decision making - related to the following elements. Firstly, the process of development of joint decisions can take a lot of time, efforts, and assets; these expenses grow with diversity and number of members, i.e., with difference of their interests. Secondly, resources are spent during attempts of emergence of coalitions and during the struggle. Thirdly, as is known from economic theory, decisions by majority of votes do not always guarantee the optimal result (theorem on median voter);

expenses for production meetings - one of the types of expenses for collective decisions related to spending time and resources for them;

expenses for provision of parties' interests - expenses related to attempts to influence the decisions by manipulating the information, conducting pressure, and using personal relations.

The following types of transaction expenses arise during motivation:

expenses for protection of employees' rights - expenses for unions within enterprise, expenses of time and resources necessary for restoration of violated rights, and losses from unreliable protection;

expenses for opportunistic behavior. The term "opportunistic behavior" was introduced by $\mathrm{O}$. Williamson to denote misbehavior which violates the terms of agreement or aimed at obtaining one-sided advantages which perform damage to partners. Expenses for opportunistic behavior consist of losses of effectiveness and expenses required for its limitation.

During the implementation of control function, the following types of transaction expenses arise most often:

expenses for information processing - expenses of time and resources related to incompleteness and imperfection of received information;

expenses for measurement - expenses of time and resources related to determination of quantity and quality of objects under control;

expenses for determination of alternatives - expenses of time and resources related to elimination of deviations of 
achieved results from the required ones through selection of various variants of solutions.

The given classification gives basis for evaluation of internal transaction expenses of industrial enterprise. High cost of direct measurements led to necessity for determination of this type of expenses with the help of high-quality method.

Within this scientific research, the authors offer expert methodology of evaluation of the level of transaction expenses at industrial enterprise. During implementation of this methodology of evaluation of the level of internal transaction expenses at industrial enterprise, related to conduct of managerial activities, the experts will be managers who work directly in organizations and know their specifics.

As a result of authors' analysis of content of main managerial functions, and on the basis of the analysis of practical activities of managers of industrial enterprise, we developed a list of criteria for the further evaluation which reflect the most peculiar types of transaction expenses with regard to top-priority types of activities of managers. The list of criteria is presented in Table 3.

Table 3. Valuation criteria

\begin{tabular}{|c|c|c|}
\hline Evaluation criteria & Maximum grade & Minimum grade \\
\hline \multicolumn{3}{|l|}{ 1. Transaction expenses emerging during implementation of organizational function } \\
\hline 1.1 Expenses caused by non-conformity of organizational structure to specifics of company work & 4 & 0 \\
\hline 1.2 Expenses caused by distribution of authorities and determination of responsibility areas & 4 & 0 \\
\hline 1.3 Expenses for provision of the process of functioning of enterprise with all required resources & 4 & 0 \\
\hline 1.4 Expenses for distributing information among enterprise's employees & 4 & 0 \\
\hline 1.5 Expenses caused by perception of the received information & 4 & 0 \\
\hline Total as to the criterion & 20 & 0 \\
\hline \multicolumn{3}{|l|}{ 2. Transaction expenses emerging during implementation of the function of planning } \\
\hline 2.1 Expenses of time and resources for acquiring information & 4 & 0 \\
\hline 2.2 Expenses of time and resources for information processing & 4 & 0 \\
\hline 2.3 Expenses of time and resources for correction of plans due to lack of information & 4 & 0 \\
\hline 2.4 Expenses of time and resources for correction of plans due to wrongly understood information & 4 & 0 \\
\hline 2.5 Expenses of time and resources for correction of plans due to non-conformance to strategic goals & 4 & 0 \\
\hline Total as to the criterion & 20 & 0 \\
\hline \multicolumn{3}{|l|}{ 3. Transaction expenses emerging during implementation of the coordination function } \\
\hline 3.1 Losses of time and resources for coordination of interests of all employees & 4 & 0 \\
\hline 3.2 Losses of time and resources for recourse against decisions of management & 4 & 0 \\
\hline 3.3 Expenses for conduct of production meetings & 4 & 0 \\
\hline 3.4 Expenses for provision of observation of employees' authorities & 4 & 0 \\
\hline 3.5 Expenses caused by manipulation of information, applying pressure, use of personal relations & 4 & 0 \\
\hline Total as to the criterion & 20 & 0 \\
\hline \multicolumn{3}{|l|}{ 4. Transaction expenses emerging during implementation of motivation } \\
\hline 4.1 Losses of time and resources for creation and support for structures of employees' interests support & 4 & 0 \\
\hline 4.2 Expenses caused by measuring the personal contribution into total result & 4 & 0 \\
\hline 4.3 Expenses caused by employees' exposure & 4 & 0 \\
\hline 4.4 Expenses caused by "idleness" at job which is related to negative stimuli & 4 & 0 \\
\hline 4.5 Expenses caused by "irreplaceability" of employee & 4 & 0 \\
\hline Total as to the criterion & 20 & 0 \\
\hline \multicolumn{3}{|l|}{ 5. Transaction expenses emerging during implementation of control function } \\
\hline 5.1 Expenses of time and resources caused by untimely receipt of information & 4 & 0 \\
\hline 5.2 Expenses of time and resources for bringing the received information to compatible form & 4 & 0 \\
\hline 5.3 Expenses caused by measurement of achieved results & 4 & 0 \\
\hline 5.4 Losses of time and resources for determination of causes for results' deviation & 4 & 0 \\
\hline 5.5 Losses of time and resources for determination of alternative variants of deviations elimination & 4 & 0 \\
\hline Total as to the criterion & 20 & 0 \\
\hline General evaluation of the level of transaction expenses & 100 & 0 \\
\hline
\end{tabular}

The evaluation is performed according to grade scale, shown in Table 4. Transaction expenses are evaluated as to the volume of losses which can emerge during performance of managerial functions and the level of regularity of their emergence. 
Table 4. Scale of evaluation of the level of transaction expenses at industrial enterprise

\begin{tabular}{|c|l|}
\hline Evaluation scale, grade & State of category \\
\hline 0 & losses for functioning of enterprise not found \\
\hline 1 & insignificant losses for enterprise functioning \\
\hline 2 & allowable losses for company \\
\hline 3 & significant losses for functioning of enterprise \\
\hline 4 & high losses for functioning of enterprise \\
\hline
\end{tabular}

Within the methodology of evaluation, the authors determine five levels of state of transaction expenses at industrial enterprise (Table 5).

Table 5. Levels of state of transaction expenses at industrial enterprise

\begin{tabular}{|c|c|l|}
\hline Level & Evaluation & Characteristics of the state of transaction expenses \\
\hline 1 & $(0-20)$ & No transaction expenses during conduct of managerial activities. \\
\hline 2 & $(20-40)$ & $\begin{array}{l}\text { Conduct of managerial activities is related to insignificant losses for functioning of enterprise, caused by transaction } \\
\text { expenses. }\end{array}$ \\
\hline 3 & $(40-60)$ & Conduct of managerial activities is accompanied by allowable losses caused by transaction expenses. \\
\hline 4 & $(60-80)$ & $\begin{array}{l}\text { Conduct of managerial activities is accompanied by significant losses for functioning of enterprise, caused by } \\
\text { transaction expenses. }\end{array}$ \\
\hline 5 & $(80-100)$ & Conduct of managerial activities is accompanied by huge losses, caused by transaction expenses. \\
\hline
\end{tabular}

General evaluation of each criterion is determined by the sum of average grades which correspond to the given criterion of evaluation categories (maximum - 20 points):

where $\mathrm{l}_{\mathrm{i}}$ - general evaluation as to criterion "i", $\mathrm{l}_{\mathrm{ij}}$ - average grade for the category, $\mathrm{j}$ - evaluation category.

General evaluation of the level of transaction expenses is determined by the sum of grades for all five evaluation criteria (maximum - 100 points):

$\mathrm{y}$ - general evaluation of the level of transaction expenses caused by managerial activities, $\mathrm{i}-$ evaluation criterion.

The advantage of this methodology of evaluation of the level of transaction expenses is the possibility for determination of the most expensive managerial functions and focusing main efforts at reduction of expenses in these spheres.

\section{Conclusion}

Transaction expenses depend also on external factors, such as informational provision, level of legislature, etc. however, enterprises cannot influence external factors, so the reduction of internal transaction expenses should be performed by means of internal perfection of enterprise management. In particular, this should be done by means of formalization of managerial activities which will allow reducing uncertainty and simplifying the cooperation of staff, and, as a consequence, lead to reduction of internal transaction expenses of enterprise, which will allow increasing the its competitiveness and effectiveness of its functioning.

It should be concluded that the given classification, as well as offered methodology for evaluation of the level of internal transaction expenses of industrial enterprise, allow the managers to see reserves of growth in the sphere of management of industrial enterprise.

\section{Acknowledgements}

The authors would like to thank the two anonymous referees and the Editor for their constructive comments and suggestions that improved our paper.

\section{References}

Vasiltsova V.M., Tertyshny S.A. Institutional economics: Study guide. - SPb.: Piter, 2013. - 256 p.

Drucker P.F. Tasks of management in XXI century: P.F. Drucker. - M.: "Williams" Publ., 2000 - 272 p.

Institutional economics: study guide / edited by G.N. Makarova, V.A. Rudyakova. - Irkutsk: BGUEP Publ., 2014. - 316 p. 
Institutional economics: study guide for academic baccalaureate / M.I. Odintsova. $-4^{\text {th }}$ edition, revised and supplemented. - M.: Yurayt Publ., 2014. $-459 \mathrm{p}$.

Institutional economics: study and practical course for baccalaureate and master course /O.S. Sukharev. — M.: Yurayt Publ., 2014. $502 \mathrm{p}$.

Cose R. Company, market, and law / R. Cose; Ed. by R. Kapelyushnikov. M.: Delo, 1993. 192 p.

Kreiner S. Key ideas of management : S. Kreiner. - M.: INFRA-M, 2002. - 347 p.

Lafta J.C. Effectiveness of organizations' management: guide / J.C. Lafta. - M.: Russian business literature, 1999. -320 p.

Milgrom P., J. Roberts. Economy, organization, and management: In 2 parts. I SPb.: Economic school, 1999. - B. 1 - 472 p., B. 2 $424 \mathrm{p}$.

Novikov D. A. Institutional management of organizational systems / D.A. Novikov. - M.: IPU RAN, 2003. - 68 p.

Rysmyatov A.Z. Theoretical and methodological basis of transactions and transaction expenses / A.Z. Rysmyatov, E.A. Sledeva, A.A. Naboka // Scientific journal KubGAU, No. 36 (2), 2008

Salikov Y.A. Systemic and functional factors of development of modern management and its instrumentarium: monograph / Y.A. Salikov. - Voronezh: Nauchnaya kniga, 2008. - 324 p.

Tabbovtsev V.L. New institutional economic theory and management / V.L. Tambovtsev // Russian journal of management, Part 4 No. 1, 2006. - p. $123-130$

Thomson A. A. Strategic management. Art of development and realization of strategy. College textbook / M.: Banks and stock exchange, UNITI. - 1998. $-576 \mathrm{p}$.

Williamson O. (1994) Comparison of alternative approaches to analysis of economic organization, A.A. Demin (ed.), Lessons of business organization, St. Petersburg, Lenizdat, 51-62.

Ustyuzhanina E.V., Dementyev V.E., Evsyukov S.G., Sukhinin I.V. Institutional economics: study guide for bachelors / edited by E.V. Ustyuzhanina. - M.: Plekhanov Russian University of Economics, 2015. - 288 p.

Furubotn E.G., Richter R. - Institutes and economic theory. Achievements of new institutional economic theory. SPb.: Publishing house of St. Petersburg State University. 2005. P. 734

Hodgson J. Economic theory and institutes. Manifest of modern institutional economic theory: Jeffrey Hodgson; Academy of National Economy with the government of the RF. - M.: Delo, 2003. - 464 p.

Khorev A.I. Institutional management of industrial enterprise and its instrumentarium / A.I. Khorev, Y.A. Salikov, L.N. Dmitrieva. Voronezh: VSTU, 2009. - $148 \mathrm{p}$.

Shastitko A.E. New institutional economic theory. - 3rd edition. - M.: Economic faculty of MSU, TEIS, 2002. - P. 188 